\title{
Can a Family Farm Benefit from Section 9006?
}

Larry Tjaden of Tjaden Farms spoke with Wind Powering America by telephone from his home in Charles City, Iowa. The Tjadens started with a simple idea: commission a wind turbine on their farmland. The family members had an unpredictable-and rewarding - journey ahead.

Tjaden Farms meets every definition of a family farm. The Tjaden brothers, Larry and Dean, and Larry's son, Scott, farm together just 12 miles north of Charles City, Iowa. Like many American farmers, the Tjadens want to continue to farm and improve their operation. But about 5 years ago, the Tjadens realized that they would need to diversify rather than rely on commodity grain farming as a primary source of revenue.

The Tjadens added a hog operation, which increased their electricity bill by $\$ 600$ per month. With electricity prices on the rise and a conviction that they would continue to rise, Larry decided to investigate a wind turbine to help with the electricity costs and further diversify the farm's assets.

Larry and Scott began with a wind resource assessment study, which indicated that their wind resource was good enough for a turbine to make economic sense. Then they explored financing. The available state and federal financial programs made wind energy even more attractive.

The Tjadens secured a loan from their local bank, along with a $0 \%$ interest loan from the Iowa Energy Center for $50 \%$ of the project costs. At the Iowa Energy Center, the Tjadens learned about the United States Department of Agriculture (USDA) Renewable Energy Grant program under Section 9006 of the 2002 Farm Bill. Section 9006 encourages rural renewable energy projects through grants of $\$ 2,500-\$ 500,000$ or up to $25 \%$ of the eligible project costs. The Tjadens decided to apply when the applications became available.

With initial financing in place, the Tjadens started looking at small turbines. Then Scott realized the greater efficiency of the bigger turbines. In Scott's mind, the ideal turbine climbed from 65 kilowatts (kW) to $100 \mathrm{~kW}$ to $225 \mathrm{~kW}$.

Finally, Scott called Larry one day and said, "Dad, I just found a used 450-kW Bonus on the Internet!"

The Bonus 450 had been installed in 1992 between Los Angeles and Palm Springs, California, along with 2,000 other wind turbines. But the turbine was taken down in 2002 because it altered wind flow for a larger turbine installed nearby. Dean and Scott flew to Palm Springs for an inspection. The Bonus 450 was exactly what they wanted.

The next question was how to get 125,000 pounds of steel and fiberglass halfway across the country. The Bonus 450 tower is a single 100 -foot piece that weighs 50,000 pounds and has a 12 -ft diameter at the bottom. How would the Tjadens coordinate the transportation details while still running their farm? The family decided to contract with Heavy Transport, a company that specializes in moving wind turbines. Larry calls this a "wise decision." Even though it cost the family $\$ 30,000$, the doorto-door delivery of the turbine saved them a lot of time and logistical headaches.

Meanwhile, the USDA had published its 2004 Notice of Funding Availability for grants under Section 9006. The Iowa Energy Center referred the Tjadens to Norm Bruce, a Business and Corporation Specialist with USDA's Rural Development in Waverly.

The USDA grant forms and documentation soon piled up and demanded many hours of the Tjadens' time to complete. Norm combed through the application, helping the family collect the appropriate documentation for each line-item detail.

Why did the Tjadens go to so much trouble, even though they knew that the project would work on its own merit? Larry said that they knew the grant would "make the project fly." And in the end, the hard work paid off.

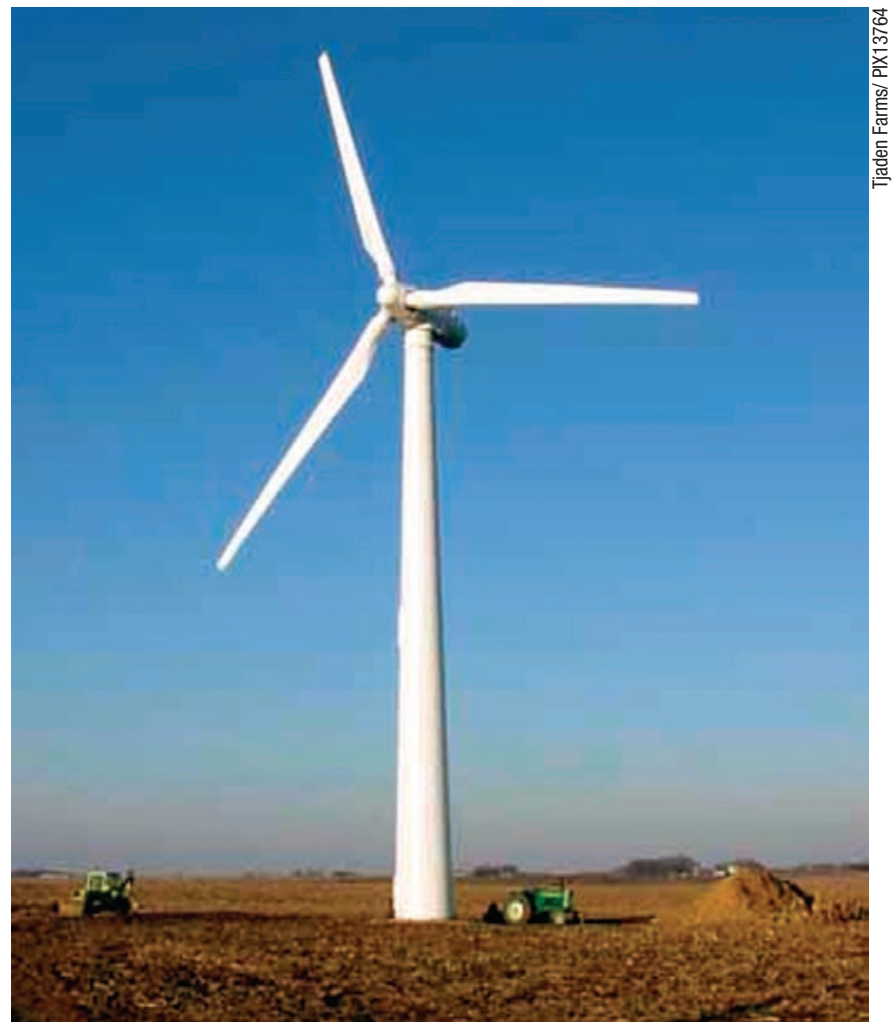

The Bonus 450-kW turbine, newly installed and in operation on a cloudless day in January 2005. 
"Scott's application was the only wind turbine approved in Iowa. Norm's line-by-line attention probably made the difference," Larry said. "We got the $\$ 45,540$ grant we requested."

Larry estimates that, assuming $\$ 2,500$ in annual maintenance and $800,000 \mathrm{kWh}$ of energy production, the project payback will be $6 \frac{1}{2}$ years. That includes the loans and grant, together with the 1.8-cent production tax credit and a 1.5-cent Iowa tax credit that should be official soon. The turbine is not net metered, so all the electricity it produces goes to the grid. The payback calculation also takes into account an agreement to sell the turbine's electricity to Dairyland Power Cooperative (DPC) of La Crosse, Wisconsin. DPC sells energy to the local cooperatives. The contract with DPC will be renegotiated in 3 years, and the Tjadens may have a chance to sell their green tags.

"The turbine was big enough that we needed a three-phase connection, not just a single phase. We had another farm on a hill with a three-phase connection near it, so we decided to locate it there," Larry said.

To take advantage of the three-phase connection, the Tjadens had to give up the ability to net meter. Turbines can only be net metered if they are near the farm facilities; if they are too far away, the turbine is considered a commercial endeavor.

"It would have been nice to net meter-that's the key for most of these projects," Larry said. "But we just couldn't justify the extra cost of installing three-phase equipment at this time."

The one issue that caught the Tjadens off guard was insurance. Again, if the wind turbine were located near farm facilities, the regular farm policy would cover the turbine. However, once the turbine was moved to a remote location to take advantage of the three-phase connection, the project was deemed a commercial endeavor.

The Tjadens scrambled to find a $\$ 1$ million insurance policy.

“DPC wouldn't interconnect us without insurance, but we had a heck of a time finding someone who was willing to insure one turbine out in the middle of nowhere. These companies are used to insuring multiple turbines," Larry said. The family's local insurance broker tracked down Aggressive Insurance, a company willing to provide the $\$ 1$ million policy for $\$ 2,172$ per year.

The physical construction/ commissioning was on schedule and yielded no surprises.

"We came out within $4 \%$ of budget, to Scott's credit. He researched everything and knew exactly where we were at all times," Larry said.

Once the turbine was safely installed and commissioned, the Tjadens wanted to see their turbine in operation. However, the wind didn't cooperate.

"We were eager to see it run, but it was dead still. We finally went home, and around nighttime the wind picked up. My daughter-in-law came by and said, 'Did you see it? That wind turbine of yours is running!' I had to drive over there and just

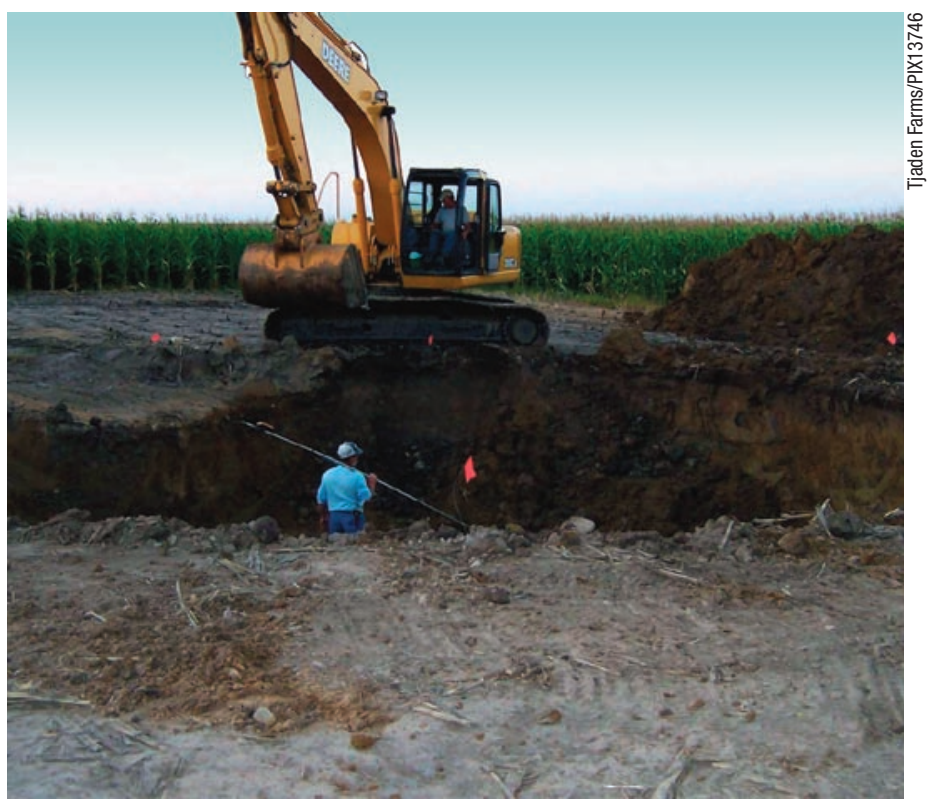

In July 2004, the excavation for the turbine foundation began.

sit and listen to it for a while," Larry said. "We took a thing that's pretty much worthless—-the wind-and created something out of it."

The turbine project was a long journey that required a lot of time and effort. But Larry thinks it was worth it.

"The project really has been a neat family project for our farm. It was just a fun, exciting project," he said. "Maybe, if this thing keeps working like it has been...well, maybe 3 or 4 years down the line, we'll be able to add another turbine. After all, we have three potential sites and plenty of high points-ample space to add another turbine."

\section{For more information about the Tjaden family's wind turbine, please contact:}

Mr. Larry Tjaden

Tjaden Farms Inc.

3223 130th St.

Charles City, IA 50616

Phone: (641) 228-4446

E-mail: larrye@fiai.net

\section{For more information about Section 9006 of the 2002 U.S. Farm Bill and how you can apply, please visit:}

www.rurdev.usda.gov/rbs / farmbill

May 2005 • DOE/GO-102005-2124 